\title{
A 'fishy' ECG in a patient with chest pain
}

\author{
V. Devesa Neto (D) - J. M. Santos · J. G. Pereira - L. Ferreira Santos · B. Marmelo
}

Accepted: 27 July 2021 / Published online: 15 September 2021

(C) The Author(s) 2021

A 71-year-old man with a past medical history of diabetes mellitus and obesity presented to his primary care physician complaining of sudden-onset anterior chest pain, which radiated to the upper left arm and was associated with nausea. Hospital transportation was complicated by three short episodes of cardiac arrest in pulseless electrical activity/asystole, which reverted after appropriate advanced life support measures, and extreme bradycardia, requiring external transcutaneous pacemaker therapy. Sedation and ventilation were required during transportation. At hospital admission, the patient had a blood pressure of $90 / 85 \mathrm{~mm} \mathrm{Hg}$ and a heart rate of $119 \mathrm{bpm}$, with signs of poor peripheral perfusion. The electrocardiogram (ECG) obtained at admission is shown in Fig. 1.

How is this electrocardiography pattern called, and what lesion is it associated with?

\section{Answer}

You will find the answer elsewhere in this issue.
Conflict of interest V. Devesa Neto, J.M. Santos, J.G. Pereira, L.Ferreira Santos and B. Marmelo declare that they have no competing interests.

Open Access This article is licensed under a Creative Commons Attribution 4.0 International License, which permits use, sharing, adaptation, distribution and reproduction in any medium or format, as long as you give appropriate credit to the original author(s) and the source, provide a link to the Creative Commons licence, and indicate if changes were made. The images or other third party material in this article are included in the article's Creative Commons licence, unless indicated otherwise in a credit line to the material. If material is not included in the article's Creative Commons licence and your intended use is not permitted by statutory regulation or exceeds the permitted use, you will need to obtain permission directly from the copyright holder. To view a copy of this licence, visit http://creativecommons.org/licenses/by/4.0/.

\footnotetext{
V. Devesa Neto $(\bowtie) \cdot J$. M. Santos · J. G. Pereira $\cdot$ L. Ferreira Santos · B. Marmelo

Cardiology Department, Tondela-Viseu Hospital Centre,

Viseu, Portugal

vandadevesaneto@gmail.com
} 


\section{Image Puzzle - Question}

E्E

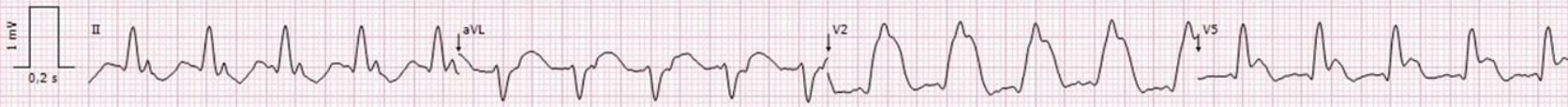

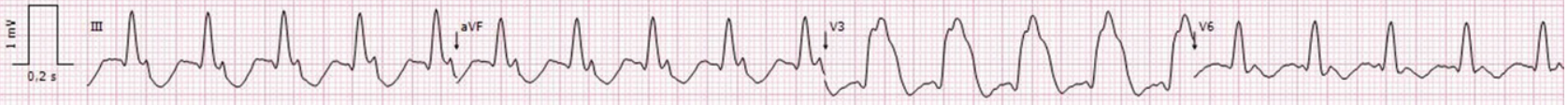

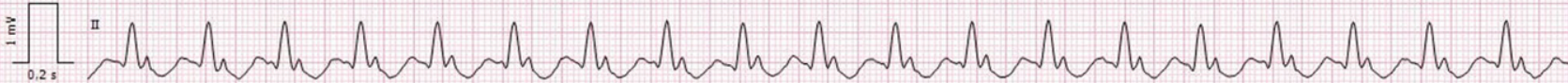

Fig. 1 Electrocardiogram at hospital admission 


\title{
Advertisement placed here.
}

\author{
ces bohn \\ LL $\begin{aligned} & \text { stafleu } \\ & \text { van loghum }\end{aligned}$ \\ Springer Media
}

Houten 2021 


\title{
Advertisement placed here.
}

\author{
ces bohn \\ LL $\begin{aligned} & \text { stafleu } \\ & \text { van loghum }\end{aligned}$ \\ Springer Media
}

Houten 2021 